\title{
THE INTERDEPENDENCE OF INDONESIA COFFEE FUTURES AND SPOT MARKET AND ITS RELATIONSHIP WITH OFFSHORE FUTURES MARKET
}

\author{
Anis Erma Wulandari*)1, Harianto ${ }^{* *}$, Bustanul Arifin ${ }^{* * *}$, and Heny K Suwarsinah*) \\ *) School of Business, IPB University \\ Jl. Pajajaran, Bogor 16151 \\ ${ }^{* *}$ Department of Agribusiness, Faculty of Economic and Management, IPB University \\ Jl. Agatis, Campus of IPB Dramaga, Bogor 16680 \\ ${ }^{* * *)}$ University of Lampung
}

Jl. Prof. Dr. Ir. Sumantri Brojonegoro No.1, Gedong Meneng, Rajabasa, Kota Bandar Lampung, Lampung 35145

\begin{abstract}
In the Indonesia coffee premature market, it is important to confirm whether the futures market has interdependence with the spot market. Moreover, as the world largest coffee producers after Brazil, Vietnam and Colombia, it is also important to examine the interdependence between Indonesia's markets with the offshore futures market whose prices are used uses for local price determination. This study examined the granger causality relationship between Indonesia futures and spot market, and granger relationship between Indonesia and the offshore futures market using data of daily Arabica and Robusta coffee prices starting from January 2014 to June 2018. The test indicated that the futures market has a stronger ability to predict the spot market; therefore, price discovery in the futures market. Bidirectional causality relationship between Arabica offshore futures and spot market indicates market demand on Arabica coffee. In general, it's identified unidirectional granger causality relationship between local and offshore futures market with information flows from the local futures market reflects the offshore market high expectation toward crop information during harvesting period both Arabica and Robusta. This is due to the importance of Indonesia's coffee crop report to world aggregate coffee production.
\end{abstract}

Keywords: commodity futures, granger causality, price volatility, spot market

\begin{abstract}
Abstrak: Pada pasar kopi Indonesia yang masih tergolong baru, menjadi hal penting untuk mengkonfirmasi apakah pasar berjangka memiliki ketergantungan dengan pasar spot. Selanjutnya, sebagai produsen kopi terbesar setelah setelah Brasil, Vietnam dan Kolombia, penting juga untuk mengetahui ketergantungan antara pasar Indonesia dengan pasar berjangka luar negeri yang harga kontrak berjangkanya digunakan untuk penentuan harga di dalam negeri. Penelitian ini menguji hubungan kausalitas antara pasar berjangka dan spot kopi di Indonesia serta hubungan pasar Indonesia dengan pasar kopi luar negeri menggunakan data harga harian kopi Arabika dan mulai dari Januari 2014 sampai dengan Juni 2018. Hasil uji menunjukkan bahwa pasar berjangka memiliki kemampuan yang lebih kuat dalam rangka memprediksi pasar spot sehingga pembentukan pasar terjadi di pasar berjangka. Hubungan kausalitas dua arah antara pasar berjangka luar negeri dan pasar spot Arabika menunjukkan permintaan pasar terhadap kopi Arabika. Secara umum, diketahui hubungan kausalitas dua arah antara pasar berjangka dalam negeri dan pasar berjangka luar negeri dengan aliran informasi dari pasar berjangka dalam yang menunjukkan harapan pasar luar negeri terhadap informasi panen selama masa panen baik untuk Arabika dan Robusta. Hal ini menunjukkan bahwa laporan hasil panen kopi Indonesia sangat penting bagi agregat pasar kopi dunia.
\end{abstract}

Kata kunci: komoditas berjangka, kausalitas granger, volatilitas harga, pasar spot

\footnotetext{
${ }^{1}$ Corresponding author:

Email: anisermaw@yahoo.com
} 


\section{INTRODUCTION}

Coffee is one agricultural commodity which considered as a risky financial activity in which farmers are significantly affected by yield risk and output price risk (Walker and Ryan, 1990; Kurosaki, 1998). This is due to the seasonality of the agricultural commodities mostly grown in certain temperate-zone countries and have strong seasonal production patterns. As a result, the biological nature of crop production plays an important role in agricultural product price behavior (Schnepf, 2006). Coffee production is not only impacted by natural factors but also by social and economic factors. It will not only depend on the climate condition and diseases but also on the cultivation method and postharvesting technology. Generally, coffee producers will be facing production risk and market risk in the form of price fluctuation and market uncertainty. In the coffee supply chain, not only farmers who have price risk exposure but also collector traders, exporters, and processors of the coffee product (Arifin, 2010). Price risk is affected not only by supply and demand but also by a market mechanism at each level from the coffee farmers up to the coffee processors that demand large coffee supply. One of the price risk indicators may be seen through coffee price volatility and price level among the markets along the supply chain. Putri et al. (2013) mentioned that farmers are price takers reflected on the unintegrated coffee markets between farmer level both in the long term and short term and coffee market in collector, cooperation and exporter levels. Coffee prices have certain spike behaviors as shown in Figures 1 and 2. Both spot price volatilities of coffee are plotted in standard deviation using 15 days of moving average numbers. The volatility of Robusta coffee was high by the end of 2014 to mid-2015 due to the impact of the decreasing of world coffee prices. It was impacted by the natural factor (heavy rainy season) in main coffee producing countries (Brazil, Vietnam and Indonesia). Indonesia spot prices are still found using offshore market prices as references in price determination; therefore, when the LIFFE (London International Financial Futures and Options Exchange) market price was impacted by the aforementioned conditions, Robusta Lampung spot price as local reference was also impacted. Considering the seasonality impacted by the weather, Indonesia also experienced the decreasing amount of Lampung Robusta export by 30\% in 2015 while the demands captured with a higher trend. This is also applied for Arabica coffee which used ICE Futures Coffee New York as reference.

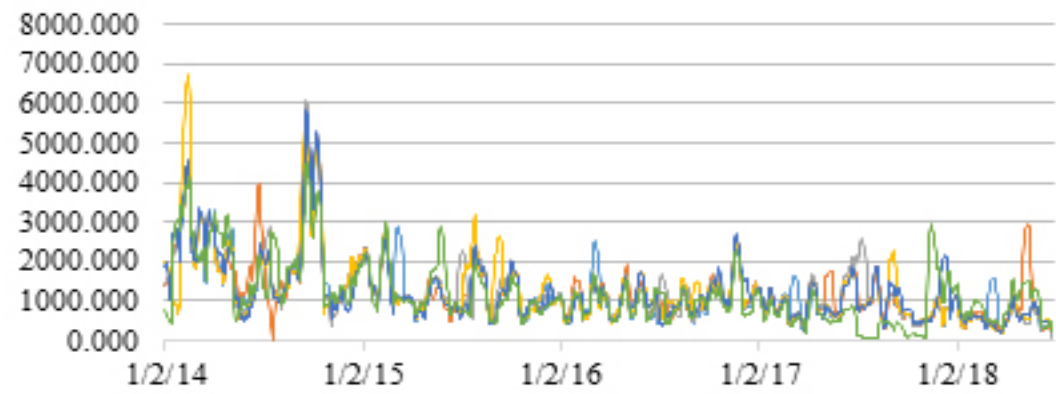

Figure 1. Arabica coffee price volatility (—ACF-MAR; — ACF-MEI; — ACF-JUL; - ACF-SEP; - ACF-DEC; - SPOTA)

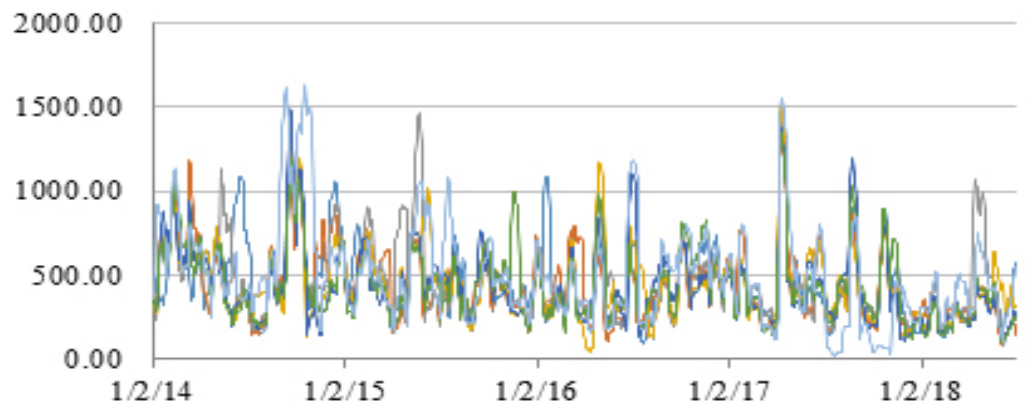

Figure 2. Volatility of Robusta coffee prices ( RCF-JAN; $\quad$ RCF-MAR; - RCF-MEI; - RCF-JUL; -RCF-SEP; - RCF-NOV; - SPOTR) 
Futures market may provide selling option to the coffee producers that they should be aware of the benefit and risk and have the access to the liquidity and technology which provide the ability for the coffee producers to access information in both markets. A futures market in Indonesia was introduced in 1997 after the issuance of Law No. 32 year 1997 and coffee futures were started to be actively traded in 2013, and it requires extra hard work to create the efficient futures market in this premature condition. Since the first trading, the coffee futures contract grew significantly by each $19.93 \%$ for $\mathrm{ACF}$ and $25.12 \%$ for RCF in 2016 and 0.71 and 13.74 in 2017. Commodity futures trading growth in overall is associated with external and internal factors. The external factor includes the increasing trend of commodity futures that encourage market participant's interest to commodity futures, and the internal factor includes economic growth, political stability condition and market positive response to government regulation on tax amnesty (Bappebti, 2017). Wibowo (2017) served empirical evidence that Jakarta Futures Exchange provides fairly good opportunities to take hedge positions in futures contracts which can reduce the volatility of portfolio returns up to $70 \%$ of the naked position in the spot market.

This research is important to be conducted to fill the gap in investigating the relationship between futures and spot market in Indonesia. Few studies on commodity futures have been performed in Indonesia such as Pertiwi (2016) and Dewi et al. (2011) that tested the coffee market efficiency and Olein in Jakarta Futures Exchange. Maulida et al. (2018) also investigated the efficient market for the cocoa commodity. More studies are required to enrich research in the futures market especially related to granger causality relationship between the futures market and the spot market as well as between the local and offshore futures market. This study investigated the relationship between markets by examining information flow of futures and spot markets and their role in price discovery and hedging instruments to coffee producers. This study empirically investigated the interdependence of futures trading to spot market in Indonesia and examined the relationship between Indonesia futures market with the offshore futures market used as a market reference for Indonesia prices. According to the aforementioned facts, we have to examine the relationship between coffee futures market and spot market and the relationship between local coffee futures market and spot market with offshore futures market considered to be developed futures market to confirm the interdependence between those markets.

\section{METHODS}

Data series of futures and spot prices were used in this study to identify price volatility and relationship between the two markets. Data consisted of 1,172 trading days starting from January 2014 to June 2018. Futures prices refer to the coffee contract prices traded in Jakarta Futures Exchange (JFX) covering all months of contracts (deliveries). Spot prices refer to certain spot market in Indonesia and include the offshore futures market price as reference for price determination with the same period referring to price reference issued by Bappebti. The offshore futures market used in this study are published in the regulator's website. All operational variables are described in Table 1.

\section{Augmented Dickey Fuller Test (Unit root Testing)}

Futures and spot prices of coffee Arabica and Robusta were first examined for stationary with Augmented Dickey Fuller (ADF) unit root test (Dickey and Fuller 1979). If the data series of prices are not stationary, the first difference will be taken to eliminate unit root problem, and the analysis was conducted on the different series. ADF unit root was tested using the following:

$$
\Delta X_{t}=b_{0}+b_{1} X_{t-1}+\sum_{t-1}^{T} b_{i} \Delta X_{t-i}+\varepsilon_{t}
$$

$\mathrm{X}_{t}$ is the first order or difference of the variables, $\Delta \mathrm{X}_{\mathrm{t}}=\mathrm{X}_{\mathrm{t}}-\mathrm{X}_{\mathrm{t}-1}$ are spot price and futures price variables, $\mathrm{T}$ is deviation white noise, $\mathrm{b}_{0}$ and $\mathrm{b}_{\mathrm{i}}$ are the estimated coefficient and $\varepsilon_{t}$ is white noise. Hypothesis of the stationary test is null hypothesis of non-stationary, and alternative hypothesis has no unit s or is stationary. We will reject null hypotheses if the p-value is less than 5\% that is series is non-stationary or series has unit roots. Therefore, we will accept the alternative hypotheses, that is, series is stationary and there is no unit root. 
Table 1. Definition of variables

\begin{tabular}{ll}
\hline Variables & Description \\
\hline Arabica spot price (SPOTA) & $\begin{array}{l}\text { Applicable price from Medan spot market. Local spot price is determined by certain } \\
\text { formula and uses offshore futures price as reference. }\end{array}$ \\
$\begin{array}{l}\text { Robusta spot price (SPOTR) } \\
\text { Arabica futures price }\end{array}$ & $\begin{array}{l}\text { Applicable price from Lampung spot market equals to Arabica spot price. } \\
\text { Settlement price of Arabica futures contract price (ACF) with several delivery dates of }\end{array}$ \\
Robusta futures price & $\begin{array}{l}\text { Settlement price of Robusta futures contract price (RCF) with several delivery dates of } \\
\text { January, March, May, July September and November }\end{array}$ \\
$\begin{array}{l}\text { ACF } \\
\text { RCF }\end{array}$ & $\begin{array}{l}\text { Arabica Commodity Futures } \\
\text { Inflation (INF) }\end{array}$ \\
$\begin{array}{l}\text { Robusta Commodity Futures } \\
\text { Exchange rate (FX) }\end{array}$ & $\begin{array}{l}\text { Consumer price index on monthly basis calculation. } \\
\text { Arabica futures price first } \\
\text { delivery (FUTAD1) }\end{array}$ \\
$\begin{array}{l}\text { Arabica futures price second } \\
\text { delivery (FUTAD2) }\end{array}$ & $\begin{array}{l}\text { Futures prices of Arabica coffee refer to ICE New York with delivery of March } \\
\text { Robusta futures price first } \\
\text { delivery (FUTRD1) }\end{array}$ \\
$\begin{array}{l}\text { Robusta futures price first } \\
\text { delivery (FUTRD2) }\end{array}$ & $\begin{array}{l}\text { Futures price of Robusta coffee refers to London Robusta Coffee Futures (LIFFE-London } \\
\text { International Financial Futures and Options Exchange) with delivery of January }\end{array}$ \\
\hline
\end{tabular}

Granger Causality Test to examine the relationship between coffee futures and spot price

Granger causality test was first introduced by Granger (1969) to examine the relationship between the two prices and its relationship between futures and spot prices with offshore market. Using regression analysis, prices are tested by testing the Arabica and Robusta futures and spot prices and vice versa. This test will evaluate whether the test found is that there is an unidirectional relationship between futures and spot market which indicates the flow of information between the two markets. Analysis will use the following models as also used by Bose (2007), Sahoo and Kumar (2009), Ali and Gupta (2011) and Sehgal et al. (2012).

$$
\begin{aligned}
& \mathrm{P}_{(\mathrm{j}) \mathrm{t}}=\alpha_{0}+\sum_{\mathrm{i}=1}^{\mathrm{n}} \alpha_{\mathrm{i}} \mathrm{P}_{(\mathrm{j})(\mathrm{t}-\mathrm{i})}+\sum_{\mathrm{i}=1}^{\mathrm{n}} \beta_{\mathrm{i}} \mathrm{F}_{\mathrm{d}(\mathrm{j})(\mathrm{t}-\mathrm{i})}+\varepsilon_{1 \mathrm{t}} \\
& \mathrm{F}_{\mathrm{d}(\mathrm{j}) \mathrm{t}}=\alpha_{0}^{\prime}+\sum_{\mathrm{i}=1}^{\mathrm{n}} \beta_{\mathrm{i}}^{\prime} \mathrm{F}_{\mathrm{d}(\mathrm{j})(\mathrm{t}-\mathrm{i})}+\sum_{\mathrm{i}=1}^{\mathrm{n}} \alpha_{\mathrm{i}}^{\prime} \mathrm{P}_{(\mathrm{j})(\mathrm{t}-\mathrm{i})}+\varepsilon_{2 \mathrm{t}}
\end{aligned}
$$

$\mathrm{P}_{(\mathrm{j}) \mathrm{t}}$ represents spot price of coffee type $\mathrm{j}$ in certain period of time of $t, F_{d(j) t}$ represent futures price coffee type $\mathrm{j}$ in certain period of time of $\mathrm{t}$ until $\mathrm{k}$ and $\mathrm{d}$ represent delivery of coffee referring to the delivery month of contract of both Arabica and Robusta, while $\varepsilon_{1 \mathrm{t}}, \varepsilon_{2 \mathrm{t}}, \varepsilon_{3 \mathrm{t}}$ dan $\varepsilon_{4 \mathrm{t}}$ are mutually uncorrelated error term.
Further analysis performs to examine the relationship between local spot and futures market as well offshore futures market using the same formula in which $F_{d(j) t}$ represents offshore futures price coffee type $\mathrm{j}$ in certain period of time of $t$ until $\mathrm{k}$ and $\mathrm{d}$ represent delivery of coffee either in the first or second delivery of Arabica and Robusta using the following models:

$$
\begin{aligned}
& \mathrm{P}_{(\mathrm{j}) \mathrm{t}}=\delta_{0}+\sum_{\mathrm{i}=1}^{\mathrm{k}} \delta_{1} \mathrm{P}_{(\mathrm{j})(\mathrm{t}-\mathrm{i})}+\sum_{\mathrm{i}=1}^{\mathrm{k}} \delta_{\mathrm{i}} \mathrm{F}_{\mathrm{d}(\mathrm{j})(\mathrm{t}-\mathrm{i})}+\varepsilon_{3 \mathrm{t}} \\
& \mathrm{F}_{\mathrm{d}(\mathrm{j}) \mathrm{t}}^{\prime}=\theta_{0}+\sum_{\mathrm{i}=1}^{\mathrm{k}} \theta_{1} \mathrm{~F}_{\mathrm{d}(\mathrm{j})(\mathrm{t}-\mathrm{i})}+\sum_{\mathrm{i}=1}^{\mathrm{k}} \alpha_{\mathrm{i}}^{\prime} \mathrm{F}_{\mathrm{d}(\mathrm{j})(\mathrm{t}-\mathrm{i})}^{\prime}+\varepsilon_{4 \mathrm{t}}
\end{aligned}
$$

The main hypothesis or null hypothesis in this research is there is no granger causality between futures and spot market at 5\% significant level. This hypothesis was also adopted by Hernandez and Torero (2009), Gupta and Varma (2015) and Xu (2015). There will be four possibilities that will be tested in this Granger Causality test related to futures and spot prices of Arabica and Robustawhetherone variable is impacting othervariable. This test will reflect whether coffee futures prices have relationship with the spot prices and vice versa toward the two types of coffees. Causality relationship may be identified as bidirectional relationship if the two coefficients of $\alpha$ and $\beta$ are statistically significant at least at $5 \%$ of significant level. Unidirectional relationship 
will be identified if causality test shows spot price is statistically significant and vice versa, and further the price will be identified as an independent variable if the analysis resulted in both coefficients are statisticlaly not significant. Critical framework of thinking in Figure 3.

\section{RESULTS}

\section{Coffee Price Information}

Arabica coffee price volatility in the period of 20142018 (as shown in Tables 2 and 3) was reflected by the coefficient of variation (CV) of $10.9 \%$ with the prices ranging between IDR54,312 (the lowest) and IDR69,170 (the highest) per kg. Arabica coffee price highest fluctuation within the last 4 years occurred in 2014 with the coefficient of variation of $13.3 \%$ and still reflected with high coefficient of variation of $11.4 \%$ in 2015. This was impacted by global factor i.e. harvesting failure in Brazil in 2014 impacting the low volume of coffee stock in the market, and many sellers tried to fulfill market expectation by selling the coffee stock and expected that coffee supply will be sufficient in the next harvesting period. The impact still occurred until 2015 (Bappebti, 2015).

Arabica coffee price was discovered to be more fluctuated compared to Robusta. This is due to the production composition where the Arabica coffee had smaller volume of production compared to Robusta and market expectation toward Arabica coffee which was lower than Robusta causing its demand to be higher after market loss of Arabica coffee stock considering the substitution effect of the two types of coffee (Nicholson and Snyder, 2008). The coefficient of variation of Robusta coffee spot price from 2014 to 2018 was $7.8 \%$ while that of Arabica was $10.9 \%$ in the same period. The same factor was found to impact this price movement. As the biggest producing country in the world, Brazil contributes significant impact to the world coffee price movement. Brazil was experiencing harvesting failure due to its high rain intensity causing failure in flowering process and decline in the coffee production in 2014, and the impact continued until 2015 (Bappebti, 2015). Wexler (2015) mentioned that as the world main coffee producer which dominates one third of world coffee production, Brazil has a major influence to the global coffee futures market compared to other producing countries.

Futures contract price also varied as shown in Table 4 in which Robusta contract with delivery of September held the highest coefficient of variation (8.4\%) followed by contract delivery of March $(8.0 \%)$. As coffee is very dependent on season, September delivery reflected market demand by end of the harvesting season and September delivery showed the market expectation just prior the start of the harvesting period.

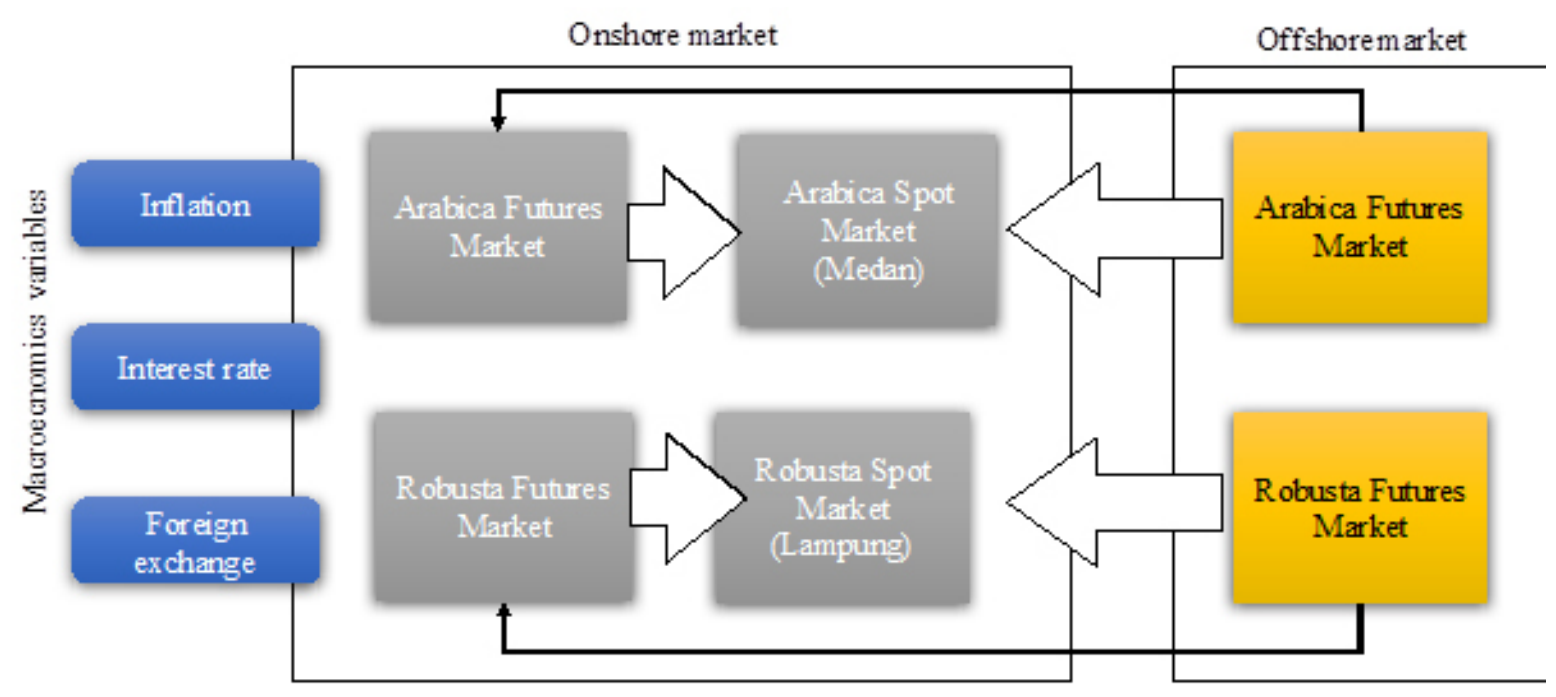

Figure 3. Critical framework of thinking 
Price risk of spot market may be hedged by taking position in futures market. Various deliveries are set in futures market and provide ability for the market participants to choose which delivery period best for them to hedge their position either in selling or buying position for coffee producers or processors. Arabica coffee futures contract (ACF) had 5 deliveries while Robusta coffee futures contract had 6 deliveries which might align with the harvesting period or buying season on the coffee consumers/processors. Arabica futures contract prices lied between IDR57,500 in minimum and IDR88,700 in maximum while Robusta coffee futures price ranged between IDR18,020 in minimum and IDR 31,010 per $\mathrm{kg}$ in maximum. Highest coefficients of variations of RCF found in contract of September (5.4\%) and November (5.4\%) (nearly end of harvesting season and after harvesting period) are shown in Table 4 and 5. Meanwhile, ACF contract coefficient of variations were found to be the highest in September (8.4\%) nearly end of harvesting season and March (8.0\%) just before the harvesting season started. Price movements are also affected by a number of extraordinary events such as foreign exchange price movements that are used as a reference and by extraordinary events in major coffee producing countries such as Brazil, Vietnam and Colombia, namely, crop failure due to weather or speculative transactions in offshore futures market (short covering) by market participants (Bappebti, 2014).

Table 2. Statistic descriptive of Arabica spot prices ${ }^{\mathrm{a}}$

\begin{tabular}{lccccc}
\hline \multicolumn{1}{c}{ Year } & Min & Max & Mean & SD $^{\mathrm{c}}$ & $\mathrm{CV}$ \\
\hline 2014 & 46,989 & 69,170 & 46,989 & 5.901 & $0.133^{\mathrm{b}}$ \\
2015 & 53,998 & 59,741 & 53,998 & 5,858 & 0.114 \\
2016 & 54,659 & 63,117 & 54,659 & 5,834 & 0.111 \\
2017 & 56,585 & 60,360 & 56,585 & 5,814 & 0.106 \\
2018 & 57,703 & 54,116 & 57,703 & 5,796 & 0.103 \\
$2014-2018$ & 54,312 & 69,170 & 54,312 & 5,776 & 0.109 \\
\hline
\end{tabular}

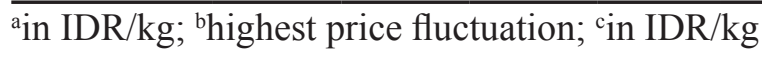

Table 3. Statistic descriptive of Robusta spot prices ${ }^{\mathrm{a}}$

\begin{tabular}{lccccc}
\hline \multicolumn{1}{c}{ Year } & Min & Max & Mean & SD $^{\mathrm{c}}$ & $\mathrm{CV}$ \\
\hline 2014 & 17,033 & 26,940 & 20,085 & 1,744 & 0.087 \\
2015 & 17,198 & 22,778 & 18,914 & 1,742 & $0.092^{\mathrm{b}}$ \\
2016 & 15,258 & 26,817 & 21,650 & 1,734 & 0080 \\
2017 & 22,087 & 27,465 & 25,056 & 1,731 & 0.069 \\
2018 & 24,277 & 24,277 & 25,414 & 1,728 & 0.068 \\
$2014-2018$ & 15,258 & 27,465 & 22,130 & 1,726 & 0.078 \\
\hline
\end{tabular}

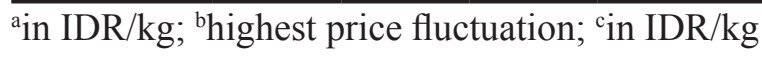

Demand of coffee in domestic market was also found to be higher due to lifestyle shifting which showed an increase of domestic consumption from 259.9 thousand tons in 2015 to 276 thousand tons in 2017 or increased by $5.8 \%$ (ICO, 2017). Indonesia coffee was also exported in several countries including United States which reached $13.05 \%$ against all coffee export volume, United Kingdom absorbed 21.05\%, and Germany and Italy absorbed 9.49 and $8.58 \%$ (BPS 2017) respectively. Coefficient of variation of coffee export reached $14.5 \%$ between 2007 and 2017 and produced a quite high volume of export proceeding income and reached USD 1 billion in 2011 and tended to increase until 2017 which reached USD 1.2 billion (ICO, 2017). Offshore market seems to be more interesting to local producers although we may not ignore the increment of domestic consumption.

Robusta coffee futures contract prices lied between IDR 18,020 in minimum and IDR19,580 in maximum per $\mathrm{kg}$. Highest coefficient of variation is shown in contract deliveries of September and November with $\mathrm{CV}$ of $5.4 \%$. This confirms that this contract demands information of coffee production by the end of harvesting period and afterward. After harvesting period, the futures price reached the highest level of IDR31,010 per kg compared to other delivery periods.

Table 4. Statistic descriptive of Arabica futures contract $(\mathrm{ACF})^{\mathrm{d}}$

\begin{tabular}{lccccc}
\hline $\begin{array}{l}\text { Delivery } \\
\text { month }^{\mathrm{e}}\end{array}$ & Min & Max & Mean & SD $^{\mathrm{f}}$ & $\mathrm{CV}$ \\
\hline MAR & 59,100 & 87,800 & 68,505 & 5,475 & 0.080 \\
MEI & 59,600 & 88,350 & 68,457 & 5,331 & 0.078 \\
JUL & 59,600 & 88,450 & 68,386 & 5,273 & 0.077 \\
SEP & 57,500 & 88,750 & 68,410 & 5,776 & 0.084 \\
DEC & 60,100 & 86,800 & 68,514 & 4,850 & 0.071 \\
\hline
\end{tabular}

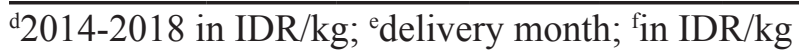

Table 5. Statistic descriptive of Robusta futures contract $(\mathrm{RCF})^{\mathrm{d}}$

\begin{tabular}{lccccc}
\hline $\begin{array}{c}\text { Delivery } \\
\text { month }^{\mathrm{e}}\end{array}$ & Min & Max & Mean & SD $^{\mathrm{f}}$ & $\mathrm{CV}$ \\
\hline JAN & 18610 & 31010 & 24808 & 1203 & 0.048 \\
MAR & 18020 & 30810 & 24787 & 1179 & 0.048 \\
MEI & 18550 & 30730 & 24748 & 1199 & 0.048 \\
JUL & 18970 & 30870 & 24914 & 1234 & 0.050 \\
SEP & 19310 & 30590 & 24875 & 1345 & 0.054 \\
NOV & 19580 & 30640 & 24892 & 1339 & 0.054 \\
\hline
\end{tabular}

d 2014-2018 in IDR $/ \mathrm{kg} ;{ }^{\text {e }}$ delivery month; ${ }^{\text {in IDR } / \mathrm{kg}}$ 
Instability of commodity prices has brought the interest in futures market considering its function as the hedging instrument and tool to mitigate the risk vulnerability. Lence (2009) mentioned that risk vulnerability is the most important matter faced by the commodity producers in developing and developed countries. Commercial participants use futures contracts to hedge their crops or inventories against the risk of fluctuated prices, e.g., processors of agricultural commodities, who need to obtain raw materials, would buy futures contracts to guard against future price rises. If prices rise (i.e. both cash and futures prices), they use the increased value of the futures contract to offset the higher cost of the physical quantities they need to purchase (Sarris et al. 2011 in Revoredo-Giha and Zuppiroli 2013). Hence, futures market is worth to be considered as one hedging instrument, if the analysis confirms that futures price plays a dominant role over the spot market. Pertiwi (2016) confirmed the result of analysis of coffee price traded in futures exchange which indicate that the Arabica coffee and Robusta coffee commodity markets have a high level of price convergence. The implication is that market participants or investors still choose to do hedging activities because the utility of futures contracts as a hedge has been effective. Maulida et al. (2018) also confirmed that commodity trading in futures market reflects efficient market and contains risk premium; therefore, hedging in futures market may be considered as sufficient in covering the price risk.

Analysis of prices and volatility plays an important role in coffee market, especially for developing countries, whose small producers and economies rely heavily on income generated by coffee trade. Price volatility plays an important role in boosting future supply and allocating existing supply, but volatility in prices may generate uncertainty about future price levels, investment and production decisions for commodity producers (Dwyer et al. 2011). Volatility has become an issue and has been widely discussed among researchers and become regulatory concern as the price may become a disincentive factor toward agricultural productivity (Kargbo, 2005). How farmers manage this risk is dictated by the institutional mechanisms in place and state of the markets in an economy. In the developed world, market-based price risk management instruments like commodity futures, options and swaps have existed for a long time; however, developing economies have only recently explored the usage of these instruments (UNCTAD 2009). In this stage, the interdependence of local futures and spot market as well as their relationship with offshore coffee futures market as described in Figure 3 is important to be examined to see whether the price discovery occurs in local futures market which reflects the efficient market and to confirm the impact of offshore coffee futures market to local market.

Ajao (2012) mentioned if markets were efficient, futures prices would become an unbiased predictor of future spot prices, and a simple prediction model would suffice, but if the market is inefficient, such predictions cannot be accurately made. The relationship between the two markets and flow information are very critical to be examined whereas the information flowing from futures to spot market is reflected considering the very premature market condition. Futures prices give necessary indications to producers and consumers about the likely future ready price and demand and supply conditions of the commodity traded. The cash market or ready delivery market: on the other hand, is a time-tested market system which is used in all forms of business to transfer title of goods. Futures and cash prices present an interesting case for application of causality-type relationships (Peck, 1985 in Jackline and Deo, 2011). Several similar researches had been performed previously such as by Sharma and Malhotra (2015) examining the causality relationship in guar seed in India, and by Sharma (2016) examining the dynamic relationship between spot price volatility and futures trading activity in India, by Gupta and Varma (2015) investigating the relationship between the futures trading activity and the spot price volatility and by Radha and Balakhrisnan (2017) studying similar thing to understand the relationship between spot and futures price.

\section{Augmented Dickey Fuller (Unit Root Testing)}

Prior to performing further analysis, the stationary of the data had to be checked. The stationary of spot price, Arabica spot price (SPOTA) and Robusta spot price (SPOTR), all futures prices of Arabica (ACF) of all delivery dates (ACFMAR, ACFMEI, ACFJUL, ACFSEP,ACFDEC) and Robusta(RCFJAN, RCFMAR, RCFMEI, RCFJUL, RCFSEP, RCFNOV) including offshore futures prices (FUTAD1, FUTAD2, FUTRD1 and FUTRD2) had been checked by Augmented DickeyFuller (ADF) test through STATA as shown in Tables 
6 and 7. Stationary is required as regression using nonstationary series provides unreliable result. In order to mitigate the price risk in spot market, producers are expected to consider the futures market performance by assessing the futures price volatility. Futures prices with various deliveries shall be able to cover the risk in spot market. Futures market performance shown in Tables 3 and 4 reflect that in general futures market has higher price compared to that of spot price. This will provide opportunity for hedgers to cover their loss if the commodity price in spot market is declining.

\section{Indonesia Futures and Spot Price Relationship}

Many economists have argued that an effective futures market should absorb information on the evolution of prices and then transmit that information to other markets (Tomek and Gray, 1970; Mattos and Garcia, 2004). Therefore, prices are "discovered" in the futures market. Price discovery is the process of new information being factored into the prices. The price discovery benefit of futures trading is predicted on the assumption that future prices reflect the combined views of a large number of buyers and sellers, all expressing their perceptions of the future value of some commodities (Fortenbery and Zapata, 1997).

Table 6. Statistical report of unit root test (in level)

\begin{tabular}{cccccccccc}
\hline & ACFMAR & ACFMEI & ACFJUL & ACFSEP & ACFDES & SPOTA & FUTAD1 & FUTAD2 & \\
\hline ADF Data & In level & In level & In level & In level & In level & In level & In level & In level & \\
t-stat & -3.745 & -3.702 & -3.636 & -3.747 & -3.839 & -5.886 & -2.455 & -2.196 & \\
p-values & 0.0574 & 0.0041 & 0.0051 & 0.0035 & 0.0025 & 0.0000 & 0.1268 & 0.2076 & \\
Coefficient & -0.0087 & -0.0157 & -0.0155 & -0.0164 & -0.0175 & -0.0369 & -0.0075 & -0.0058 & \\
Decision & Accept & Accept & Accept & Reject & Reject & Reject & Accept & Accept & \\
& H0 & H0 & H0 & H0 & H0 & H0 & H0 & H0 & \\
\hline & RCFJAN & RCFMAR & RCFMEI & RCFJUL & RCFSEP & RCFNOV & SPOTR & FUTRD1 & FUTRD2 \\
\hline ADF Data & In level & In level & In level & In level & In level & In level & In level & In level & In level \\
t-stat & -2.970 & -2.904 & -3.245 & -2.806 & -2.823 & -2.773 & -2.637 & -2.317 & -2.093 \\
p-values & 0.0378 & 0.0449 & 0.0175 & 0.0574 & 0.0550 & 0.0623 & 0.0856 & 0.1666 & 0.2472 \\
Coefficient & -0.0101 & -0.0095 & -0.0120 & -0.0087 & -0.0086 & -0.0083 & -0.0088 & -0.0064 & -0.0053 \\
Decision & Accept & Accept & Accept & Accept & Accept & Accept & Accept & Accept & Accept \\
& H0 & H0 & H0 & H0 & H0 & H0 & H0 & H0 & H0 \\
\hline
\end{tabular}

Note: MacKinnon (1996) 5\% critical value: -2.860 ; p-value is significant in 5\%

Table 7. Statistical report of unit root (first difference)

\begin{tabular}{cccccccccc}
\hline & ACFMAR & ACFMEI & ACFJUL & ACFSEP & ACFDES & SPOTA & FUTAD1 & FUTAD2 & \\
\hline ADF Data & 1 st diff & 1 st diff & 1 st diff & In level & In level & In level & 1 st diff & 1 st diff & \\
t-stat & -41.500 & -41.607 & -42.606 & -3.747 & -3.839 & -5.886 & -43.871 & -43.480 & \\
p-values & 0.000 & 0.000 & 0.000 & 0.0035 & 0.0025 & 0.0000 & 0.000 & 0.000 & \\
Coefficient & -1.0261 & -1.0285 & -1.0519 & -0.0164 & -0.0175 & -0.0369 & -1.0809 & -1.0719 & \\
Decision & Reject & Reject & Reject & Reject & Reject & Reject & Reject & Reject & \\
& H0 & H0 & H0 & H0 & H0 & H0 & H0 & H0 & \\
\hline & RCFJAN & RCFMAR & RCFMEI & RCFJUL & RCFSEP & RCFNOV & SPOTR & FUTRD1 & FUTRD2 \\
\hline ADF Data & 1st diff & 1 st diff & 1 st diff & 1st diff & 1st diff & 1 st diff & 1 st diff & 1 st diff & 1 st diff \\
t-stat & -45.139 & -44.425 & -46.415 & -43.962 & -43.922 & -44.710 & -51.420 & -44.402 & -43.088 \\
p-values & 0.000 & 0.000 & 0.000 & 0.000 & 0.000 & 0.000 & 0.000 & 0.000 & 0.000 \\
Coefficient & -1.1064 & -1.0936 & -1.1409 & -1.0852 & -1.0842 & -1.1013 & -1.2360 & -1.0921 & -1.0612 \\
Decision & Reject & Reject & Reject & Reject & Reject & Reject & Reject & Reject & Reject \\
& H0 & H0 & H0 & H0 & H0 & H0 & H0 & H0 & H0 \\
\hline
\end{tabular}

Note: MacKinnon (1996) 5\% critical value: -2.860 ; $\mathrm{p}$-value is significant in 5\% 
Furthermore, information flow between the two markets is also an important part that needs to be examined. This is to prove whether information flows from one market to another to support the Efficient Market Hypothesis. Granger causality test is widely used by researchers to examine whether there is a short-term relationship between the two markets. Table 8 shows the result of analysis between Indonesia futures and spot market which exhibits mostly unidirectional causality relationship from futures to spot market and reveals that futures market dominates spot market for both Arabica and Robusta coffee confirming the price discovery in futures market. Bidirectional relationship is also found in certain months of contracts especially in September for Arabica (nearly end of harvesting period) and in November for Robusta (just after the harvesting period). This result indicates that futures market (all deliveries) provides a positive signal to spot market that futures market is a predictor to the spot price, and futures market dominates spot market that is price discovery in futures market. Bidirectional causality relationship of Arabica contracts of September delivery and November delivery for Robusta reveals that market demands crop information to define the actual market supply nearly at the end and post harvesting season. This study is in line with the research performed by Ge (2010) confirming that bidirectional causality relationship between markets is contribute by many factors, one of which is significant bilateral trade numbers.
Srinivasan (2010) studied the relationship between futures and spot market and found the bidirectional relationship in which volatility in spot markets was impacted by volatility in futures market and vice versa. Gupta and Varma (2015) used granger causality test and produced unidirectional relationship from futures market return to spot market and futures markets which formulate spot market indicating the price discovery. These research findings are consistent with the findings of Yang et al. (2005), but it is contradictory to the findings of Darrat and Rahman (1995) and Iyer and Mehta (2007) who reflect that futures market dominates the spot market. The information appears first in the futures market and then is transmitted down to the spot market. As a result, futures market may enjoy greater leverage which in turn attracts the speculators. Greater speculative activity provides liquidity to the market and helps in price discovery (Chakraborty and Das 2013). Furthermore, Working (1948) refers it to price discovery function in futures market facilitated by the participation of hedgers and speculators that provide liquidity and information to the market. The existence of speculator should not be limited to bring the liquidity in the market, and therefore, any regulation limits their role may not benefit the market.

Table 8 . Granger causality test between local spot and futures market

\begin{tabular}{|c|c|c|c|c|c|c|c|}
\hline \multicolumn{2}{|c|}{ Commodity } & \multirow{2}{*}{ Hypotheses } & \multirow{2}{*}{$\begin{array}{l}\text { Reject/ } \\
\text { Accept }\end{array}$} & \multicolumn{2}{|c|}{ P-value ${ }^{a}$} & \multirow[b]{2}{*}{ Direction } & \multirow[b]{2}{*}{ Relationship } \\
\hline Variables (1) & Variables (2) & & & FUT $^{\mathrm{b}}$ & $\mathrm{SPOT}^{\mathrm{C}}$ & & \\
\hline \multicolumn{8}{|l|}{ Arabica } \\
\hline \multirow[t]{5}{*}{ D(SPOTA) } & D(ACFMAR) & D(ACFMAR) does not cause D(SPOTA) & Reject & 0.000 & 0.588 & Unidirectional & $\mathrm{D}($ ACFMAR $) \rightarrow \mathrm{D}$ (SPOTA) \\
\hline & $\mathrm{D}$ (ACFMEI) & D(ACFMEI) does not cause D(SPOTA) & Reject & 0.000 & 0.064 & Unidirectional & D(ACFMEI) $\rightarrow$ D(SPOTA) \\
\hline & D(ACFJUL) & D(ACFJUL) does not cause D(SPOTA) & Reject & 0.000 & 0.188 & Unidirectional & $\mathrm{D}(\mathrm{ACFJUL}) \rightarrow \mathrm{D}$ (SPOTA) \\
\hline & D(ACFSEP) & D(ACFSEP) does not cause D(SPOTA) & Reject & 0.000 & 0.004 & Bidirectional & $\mathrm{D}(\mathrm{ACFSEP}) \leftrightarrow \mathrm{D}$ (SPOTA) \\
\hline & D(ACFDES) & D(ACFDES) does not cause D(SPOTA) & Reject & 0.000 & 0.643 & Unidirectional & $\mathrm{D}(\mathrm{ACFDES}) \rightarrow \mathrm{D}(\mathrm{SPOTA})$ \\
\hline \multicolumn{8}{|l|}{ Robusta } \\
\hline \multirow[t]{6}{*}{ D(SPOTR) } & D(RCFJAN) & D(RCFJAN) does not cause D(SPOTR) & Reject & 0.000 & 0.194 & Unidirectional & $\mathrm{D}($ RCFJAN $) \rightarrow \mathrm{D}(\mathrm{SPOTR})$ \\
\hline & D(RCFMAR) & D(RCFMAR) does not cause D(SPOTR) & Reject & 0.000 & 0.102 & Unidirectional & $\mathrm{D}($ RCFMAR $) \rightarrow \mathrm{D}($ SPOTR $)$ \\
\hline & $\mathrm{D}$ (RCFMEI) & $\mathrm{D}$ (RCFMEI) does not cause $\mathrm{D}$ (SPOTR) & Reject & 0.000 & 0.081 & Unidirectional & $\mathrm{D}($ RCFMEI $) \rightarrow \mathrm{D}$ (SPOTR) \\
\hline & D(RCFJUL) & $\mathrm{D}$ (RCFJUL) does not cause D(SPOTR) & Reject & 0.000 & 0.215 & Unidirectional & $\mathrm{D}$ (RCFJUL) $\rightarrow$ D(SPOTR $)$ \\
\hline & D(RCFSEP) & D(RCFSEP) does not cause D(SPOTR) & Reject & 0.000 & 0.026 & Unidirectional & $\mathrm{D}$ (RCFSEP) $\rightarrow$ D(SPOTR) \\
\hline & $\mathrm{D}(\mathrm{RCFNOV})$ & D(RCFNOV) does not cause D(SPOTR) & Reject & 0.000 & 0.001 & Bidirectional & $\mathrm{D}(\mathrm{RCFNOV}) \leftrightarrow \mathrm{D}$ (SPOTR $)$ \\
\hline
\end{tabular}

${ }^{a}$ significant in level $5 \%$; ${ }^{b} \mathrm{p}$-value when $\mathrm{F}$ is the predictor; ${ }^{\mathrm{c}}$ when $\mathrm{S}$ is the predictor 


\section{Indonesia and Offshore Futures Market Relationship}

Table 9 reveals an interesting fact regarding the relationship between local and offshore futures market. Bidirectional causality relationship is found from local Arabica spot market and offshore Arabica futures market first delivery which reflects offshore demand toward Arabica coffee as global coffee production dominated by Arabica coffee (ICO, 2017). Unidirectional causality relationship is found between local Arabica futures contracts of all deliveries and offshore Arabica futures contract first delivery while bidirectional relationship is discovered between Arabica futures contracts of all deliveries and offshore Arabica futures contract second delivery. Unidirectional causality relationship is revealed between offshore Robusta futures contract first and second deliveries to spot market, and in general, bidirectional causality relationship is found between local futures market and offshore futures market except contracts with deliveries of January, July and September identified having unidirectional causality relationship with offshore futures market second delivery with flow of information from local futures market.
This study reflects Indonesia production information especially during and nearly end of harvesting period which confirms the Indonesia firm position as the 4th world biggest coffee producer; therefore, Indonesia coffee production plays an important role in determining world coffee prices. As the 4th biggest coffee producer, information on production is expected by the local and offshore markets by considering the significant amounts of Indonesia coffee export volume. According to ICO latest report, Indonesia coffee plays an important role in revising total world coffee production. Indonesia coffee production for crop in the period of 2016/17 was revised up to 153.9 million bags, compared to ICO previous estimate of 151.6 million. This was mostly due to an increase in output from Indonesia, revised up from 10 million bags to 11.5 million and a significant revision from Peru by 4.2 million bags. While production in Colombia has recovered strongly since the coffee leaf rust crisis, growth is slowly tapering off. Annual growth rates steadily decreased from $9.7 \%$ in 2014/15 to an estimated 3.5\% in 2016/17 (ICO, 2017). This study discovers the relationship of local and offshore futures markets and information flow from Indonesia market to offshore markets and confirms the importance of Indonesia coffee production toward world coffee production/market.

Table 9. Granger causality test between local spot market and offshore futures market

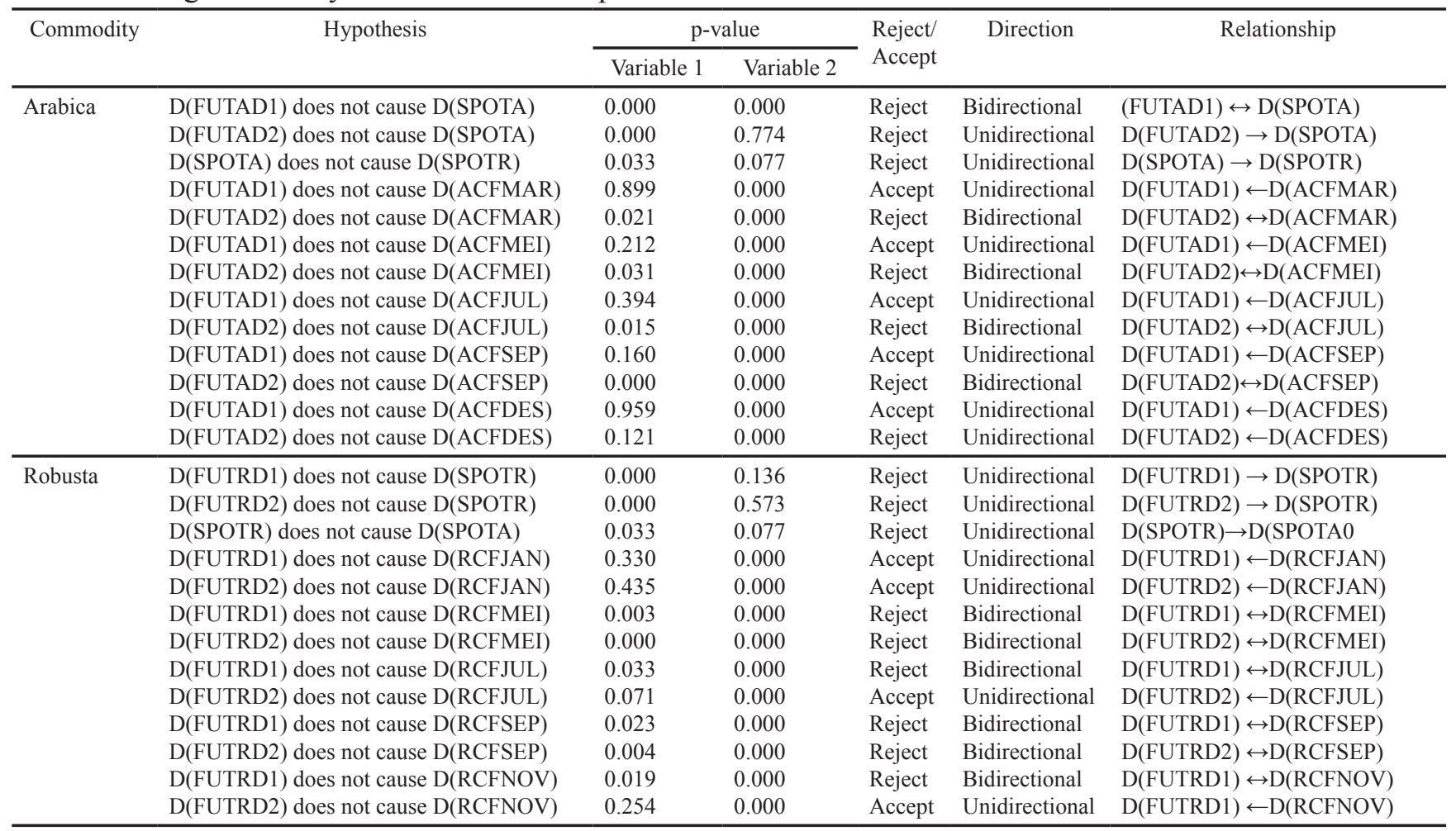

Note: significant in level 5\% 
As also reported in 2017/18, Brazil had also reported experiencing a specific agronomic and wider economic factor potentially affecting coffee supply. Reports showed that farmers in Brazil's Arabica-growing regions were harvesting the 2017/18 crop and facing with unexpectedly low yields. Beans were smaller than usual due to unfavorable weather conditions earlier in the season. This was exacerbated by considerable damage resulting from berry borer infestation. The ban on use of the highly controversial but effective endosulfan insecticide used by farmers in the past has led to significant spread of this pest. Up to $30 \%$ of the crop is estimated to have been affected in major growing areas, with a negative impact on bean quality. Finally, besides these agronomic factors, the weakening US dollar lowered the competitiveness of Brazilian coffee on the world market, hampering exports. What had been experienced by Brazil was then transferred to Indonesia as Brazil has the most powerful role in the market to influence price movement in offshore futures market and its price is utilized by Indonesia as market reference. This study explored the flow of information impacting price volatility due to the activity of coffee futures contracts during the period of 2014-2018. Overall results indicate that crop reports generally affect price volatility. The impact is particularly stronger when they provide information following the flowering periods in Colombia, Brazil, and Vietnam, the world's major producers (Silveira, 2016).

\section{Managerial Implications}

\section{Hedgers}

Analysis result indicates that volatility in the futures market will be impacting volatility in the spot market which confirms the future market domination over the spot market. This is then confirming the importance of futures price information to spot market especially producers in general or farmers in particular. All market participants and other relevant stakeholders especially farmers as the main producers will have the same access to price information both spot and futures prices. Should all parties in the whole coffee supply chain, especially farmers, are equipped by price information, they will have selling option in which they do not directly sell their coffee to collector traders but have possibility to sell the coffee to the nearest spot market especially when the futures price is the unbiased predictor of the spot prices which then benefit farmer in optimizing their income by choosing the market where they wish to sell their coffee. In addition, futures market is considerably effective as hedging instrument as it provides opportunity for hedgers to cover their loss if the commodity price in spot market is declining.

\section{Regulator}

Bappebti as a regulator shall provide accessible price information to the producers especially farmers. Considering technical limitation in farmer level, price information shall be accessible by the groups of farmers and/or cooperation. For policy makers, it is important to know whether futures markets or cash markets dominate the price setting. Based on the research performed by Arnade and Hoffman (2015), agricultural policy makers often focus on cash markets, whereas many economists argue that futures markets are more liquid, can absorb new information more quickly, and thus contributing more to price discovery than cash markets. This serves as a reminder that both producers and policy makers should pay closer attention to futures markets when evaluating and forecasting economic outcomes in agriculture. This research provides empirical evidence to the regulator that price discovery happens in the futures market which may become an unbiased predictor of the spot market and information to the producers, and hedger, in general, is important; therefore, maximizing the role of warehouse managers and/or auction market infrastructure as an agent of information may contribute to producers/ hedgers decision making whether they would like to sell in the spot market or store it and take position in the spot market or sell coffee to collector traders without bothering to calculate the cost and optimum income that they wish to have.

Futures market strong domination over the spot market might be considered as a hedging instrument to cover spot price risk; however, there are also some potential issues in the futures market that need the government or regulatory attention for better implementation. Trading volume will depend on the contract size which may impose producers for under hedge or over hedge of total commodity physical holding. Type of coffee is only opened for Arabica and Robusta while Indonesia has many types of coffee such as Liberica and Lintong; however, guidance from regulator perhaps may help producers to use price references of producers if they wish to hedge their position. Warehouse location is also one of the unique issues in Indonesia considering each 
island is separated by sea and creates transactional costs or other fees if the sellers wish any physical delivery trough futures market. Arabica coffee delivery points are located in several registered warehouses located in Medan, Makassar, Jakarta and Surabaya while Robusta coffee is in Palembang, Bandar Lampung, Jakarta and Surabaya. These delivery warehouse options will rely on seller preference. As coffee grows in almost 34 provinces in Indonesia, this will become a challenge as well, as the sellers will not only consider the land transportation but also sea transportation, delivery fee and also other transactional costs which will be the responsibility of the sellers. Hence, cost calculation shall be very accurate in order for them to gain potential optimum income. Furthermore, as confirmed by ICO (2017), information on Indonesia coffee production may revise world coffee production, it is then important for Indonesia to elevate and immediately execute the grand plan for coffee rejuvenation and/or replantation to increase the production or at least maintain the production level.

\section{CONCLUSIONS AND RECOMMENDATIONS}

\section{Conclusions}

Unidirectional causality relationship is found at the local Arabica and Robusta spot markets while the bidirectional causality relationship is found between Arabica futures contract of September and Robusta futures contract of November which reflects the importance of production information by the end and after harvesting period. Bidirectional causality relationship is found at the local Arabica spot market and offshore Arabica futures market first delivery which reflects offshore demand toward Arabica coffee as global coffee production is dominated by Arabica coffee. Unidirectional causality relationship is found between local Arabica futures contracts in all deliveries and offshore Arabica futures contract first delivery while the bidirectional relationship is discovered between Arabica futures contracts of all deliveries and offshore Arabica futures contract second delivery. Unidirectional causality relationship is revealed between offshore Robusta futures contract first and second deliveries and spot market. In general, bidirectional causality relationship is found between local futures market and offshore futures market for except contracts of deliveries of January, July and September in which they were identified having unidirectional causality relationship with offshore futures market second delivery with flow of information from local futures market. This study reflects Indonesia's production information especially during and nearly the end of harvesting period which confirms that the Indonesia firm's position is the 4th world biggest coffee producer. This indicates that Indonesia coffee production plays an important role in determining world coffee prices together with the other world producing countries.

\section{Recommendations}

Considering the minimum access of producers especially farmers to price information and the result of analysis which found that futures market dominates spot market and reflects price discovery in futures market, it will be beneficial if producers have access to market information especially to those who live near with spot and/or auction market. Future research on the access to information will provide evidence on identification of certainties equivalent to income (CEI) in producers especially at farmer level i.e. those who live near the spot market. This is to confirm whether the access to price information in spot market may actually contribute to their optimum income.

\section{REFERENCES}

Ajao Y. 2012. Performance Prediction of Commodity Prices using Foreign Exchange Futures. Walden: Walden University.

Ali J, Gupta KB. 2011. Efficiency in agricultural commodity futures markets in india: evidence from cointegration and causality tests. Agricultural Finance Review 71(2): 162-178. https://doi.org/10.1108/00021461111152555.

Arifin B. 2010. Global sustainability regulation and coffee supply chains in Lampung Province, Indonesia. Asian Journal of Agriculture and Development 7(2): 67-89.

Arnade C, Hoffman L. 2015. The impact of price variability on cash/futures market relationships: implications for market efficiency and price discovery. Journal of Agricultural and Applied Economics 47(4): 539-559. https://doi. org/10.1017/aae.2015.24.

[Bappebti] Badan Pengawas Perdagangan Berjangka Komoditi. 2014. Analisis Harga Kopi Robusta Pekan Keempat Mei 2014. Jakarta: Bappebti

Bose S. 2007. Commodity futures market in India: a 
study of trends in the notional multi-commodity indices. ICRA Bulletin 3(3): 125-158.

[BPS] Badan Pusat Statistik. 2017. Ekspor Kopi Menurut Negara Tujuan Utama. Jakarta: BPS.

Darrat AF, Rahman S. 1995. Has futures trading activity caused stock price volatility. Journal of Futures Market 15(5): 537-557. https://doi.org/10.1002/ fut.3990150503.

Dewi A, Siregar H, Manurung AH. 2011. Analisis kontrak berjangka olein di bursa berjangka Jakarta. Jurnal Manajemen dan Agribisnis 8(1): $1-9$.

Dickey D, Fuller WA. 1979. Distribution of the estimators for time series regressions with unit roots. Journal of the American Statistical Association 74: 427-431. https://doi.org/10.108 0/01621459.1979.10482531.

[DIRJENBUN] Direktorat Jenderal Perkebunan. 2016. Statistik Perkebunan Indonesia: Kopi. Jakarta: DIRJENBUN

Dwyer A, Gardner G, William T. 2011. Global Commodity Markets - Price Volatility and Financialization. Reserve Bank of Australia: Report/Bulletin.

Ge Y. 2010. Three essays on price analysis of selected agricultural commodities [dissertation]. Indiana: Pudue University.

Granger C. 1986. Developments in the Study of Cointegrated Variables. Oxford Bulletin of Economics and Statistics 48(3): 213-227. https://doi.org/10.1111/j.1468-0084.1986. mp48003002.x.

Gupta A, Varma P. 2015. Impact of futures trading on spot markets: an empirical analysis of rubber India. Eastern Economic Journal 42(4210): 373386. https://doi.org/10.1057/eej.2014.64.

[ICO] International Coffee Organization. 2017. Source: https://www.indonesia-investments.com/id/ bisnis/komoditas/kopi/item186 [6 Juni 2017].

Iyer V, Mehta. H. 2007. Price Discovery and Convergence in the Indian Commodities Market: A Two Regime Threshold VAR Approach. Paper presented at the National Workshop on Commodity Research, NCDEX Institute of Commodity Markets \& Research (NICR).

Jackline S, Deo M. 2011. Lead-lag relationship between the futures and spot prices. Journal of Economics and International Finance 3(7): 424-427.

Kargbo J. 2005. Impacts of of monetary and macroeconomic factors on food prices in West Africa. Agrekon 44(2): 205-224. https://doi.org/

\subsection{0/03031853.2005.9523710.}

Lence SH. 2009. Do futures benefit farmers?. American Journal of Agricultural Economics 91(1): 154-167. https://doi.org/10.1111/j.14678276.2008.01162.x.

Mattos F, Garcia P. 2004. Price Discovery in Thinly Traded Markets: Cash and Futures Relationships in Brazilian Agricultural Futures Markets. paper presented at the NCR-134 Conference on Applied Commodity Price Analysis, Forecasting, and Market Risk Management held on April 19-20, St. Louis, Missouri.

Maulida R, Anggraeni L, Pasaribu SH. 2018. Testing of market efficiency of the cacao commodity for the futures market in Jakarta Futures Exchange. Jurnal Manajemen \& Agribisnis 15(1): 53-60. https://doi.org/10.17358/jma.15.1.53.

Nicholson W, Snyder C. 2008. Microeconomic Theory: Basic Principles and Extension. Ohio: Thomson South-Western.

Pertiwi D. 2016. Pengujian efisiensi pasar dan tingkat konvergensi harga komoditas kopi arabika dan kopi robusta (studi kasus pada pasar komoditas berjangka di Indonesia). Jurnal Manajemen Pemasaran 9(2): 43-53. https://doi.org/10.9744/ pemasaran.9.2.43-53.

Putri MA, Fariyanti A, Kusnadi N. 2013. Struktur dan integrasi pasar kopi arabika gayo di Kabupaten Aceh Tengah dan Bener Meriah. Buletin RISTI 4(1):47-54.

Radha K, Balakrishnan K. 2017. The Role of Commodity Futures in Risk Management: A Study of Select Agricultural Commodities. The IUP Journal of Financial Risk Management 14(14): 7-29.

Revoredo-Giha C, Zuppiroli M. 2013. Commodity futures markets: are they an effective price risk management tool for the european wheat supply chain?. Journal of Bio-based and Applied Economics 2(3): 237-255.

Sahoo P, Kumar R. 2009. Efficiency and futures tradingprice nexus in Indian commodity futures markets. Global Business Review 10 (2): 187-201. https:// doi.org/10.1177/097215090901000204.

Schnepf R. 2006. Price Determination in Agricultural Commodity Markets: A Primer. Congressional Research Service - Report for Congress. 39

Sehgal S, Rajput N, Dua RK. 2012. Price discovery in Indian agricultural commodity markets. International Journal of Accounting and Financial Reporting 2(2): 34-54. https://doi. org/10.5296/ijafr.v2i2.2224. 
Sharma P. 2016. Impact Analysis of Commodity Futures on Spot Prices, and Risk Management in Essential Commodities. NIAM Research Report. Rajasthan: CCS National Institute of Agricultural Marketing (Ministry of Agriculture, Govt. of India).

Sharma DK, Malhotra M. 2015. Impact of of futures trading on volatility of spot market- a case of guar seed. Journal of Agricultural Finance Review 75(3): 416-431. https://doi.org/10.1108/ AFR-03-2014-0005.

Silveira RL. 2016. The reaction of coffee futures price volatility to crop reports. Journal of Emerging Market Finance and Trade 53(10): 2361-2376. https://doi.org/10.1080/1540496X.2016.120597 6.

Srinivasan P. 2010. Price discovery and volatility spillovers in indian spot-futures commodity market.. The IUP Journal of Behavioral Finance 65(1): 101-120.

Tomek WG, Gray RW. 1970. Temporal relationships among prices on commodity futures markets: their allocative and stabilizing roles. American
Journal of Agricultural Economics 48: 372-380. https://doi.org/10.2307/1237388.

[UNCTAD] United Nation Conference of Trade and Development. 2009. Trade and Development Report 2009. Geneva: UNCTAD.

Walker TS, Ryan JG. 1990. Village and Household Economics in India's Semi-arid Tropics. Baltimore: Johns Hopkins University Press.

Wibowo B. 2017. Hedging ratio measurement methods and hedging effectiveness in Jakarta Futures Exchanges. Jurnal Ekonomi Pembangunan 18(1): 118-130. https://doi.org/10.23917/jep. v18i1.3473.

Xu X. 2015. Causality, price discovery, and price forecasts: evidence from u.s. corn cash and futures markets [dissertation]. Nort Carolina: North Carolina State University.

Yang J, Brian, BR, Leatham DJ. 2005. Futures trading activity and commodity cash price volatility. Journal of Business Finance Accounting 32(1-2): 297-323. https://doi.org/10.1111/ j.0306-686X.2005.00595.x. 